\title{
SISTEM REKOMENDASI LOKASI MAGANG BERDASARKAN KOMPETENSI BERBASIS ARTIFICIAL INTELLIGENCE UNTUK LULUSAN DEMAND DRIVEN (STUDI KASUS : JURUSAN MANAJEMEN INFORMATIKA, UNDIKSHA)
}

\author{
Agus Aan Jiwa Permana', Gede Aditra Pradnyana² \\ Program Studi Manajemen Informatika ${ }^{1)}$ \\ Program Studi Pendidikan Teknik Informatika ${ }^{2)}$ \\ Universitas Pendidikan Ganesha 1) 2) \\ Agus.aan@undiksha.ac.id ${ }^{1)}$ gede.aditra@undiksha.ac.id ${ }^{2)}$
}

\begin{abstract}
This research is aimed at providing student location information to students in accordance with their respective competencies. The most important thing is to direct students to an apprenticeship location that is in accordance with their competencies because it will greatly influence their career in the future. Armed with skills at the internship location, students can improve their competence in accordance with market demand (demand driven). The program at the end of semester 5 at the end of the semester students have to find an internship location. Someone is said to be competent in a field if it meets the aspects of knowledge, skill and attitude. Knowledge, skills and attitudes (PKS) are strongly influenced by the learning system and learning environment. The tools developed are an application based on Artificial Intelligence using the Elman Recurrent Neural Network (ERNN) method. ERNN is a Artificial Terms Network method that has a feedback connection from previous input, so that it is expected to improve the performance of ANN. The structure makes iteration will be much faster and convergence will be faster in the training process. The system developed will be able to produce apprenticeship location recommendations in accordance with student competencies using previous apprenticeship data. The data used is measurable and includes a Grade Point Average that represents aspects of knowledge, aspects of skills adapted to subjects related to graduate profiles, personality tests that have international standards developed by John Holland represent aspects of attitude.
\end{abstract}

Keywords : Recommended internship locations, Artificial Terms Network, Artificial Intelligence, demand driven, Successful career in Industry

\begin{abstract}
ABSTRAK
Penelitian ini adalah bertujuan memberikan informasi lokasi magang kepada mahasiswa sesuai dengan kompetensi masing-masing. Hal yang paling penting adalah mengarahkan mahasiswa ke lokasi magang yang sesuai dengan kompetensinya karena akan sangat besar pengaruhnya dengan karir mereka di masa depan. Dengan berbekal keterampilan di lokasi magang, mahasiswa dapat meningkatkan kompetensinya sesuai dengan permintaan pasar (demand driven). Program saat akhir semester 5 di akhir semester mahasiswa sudah harus mencari lokasi magang. Seseorang dikatakan kompeten di suatu bidang apabila memenuhi telah memenuhi aspek pengetahuan, keterampilan, dan sikap. Pengetahuan, keterampilan, dan sikap sangat dipengaruhi oleh sistem pembelajaran dan lingkungan belajar. Tools yang dikembangkan adalah sebuah aplikasi berbasis Artificial Intelligence menggunakan metode Elman Recurrent Neural Network (ERNN). ERNN adalah sebuah metode Jaringan Syarat Tiruan yang memiliki koneksi umpan balik dari masukan sebelumnya, sehingga diharapkan dapat meningkatkan kinerja JST. Struktur tersebut membuat iterasi akan jauh lebih cepat dan konvergensi akan menjadi lebih cepat dalam proses training. Sistem yang dikembangkan akan dapat menghasilkan rekomendasi lokasi magang sesuai dengan kompetensi mahasiswa menggunakan data magang sebelumnya. Adapun data yang digunakan bersifat terukur dan meliputi ketiga aspek PKS seperti Indeks Prestasi Kumulatif yang mewakili aspek pengetahuan, aspek keterampilan disesuaikan dengan mata kuliah yang berhubungan dengan profil lulusan, tes kepribadian yang sudah berstandar internasional yang dikembangkan oleh John Holland mewakili aspek sikap.
\end{abstract}


Kata kunci: Rekomendasi lokasi magang, Jaringan Syarat Tiruan, Artificial Intelligence, demand driven, Sukses berkarir di Industri

\section{PENDAHULUAN}

Program magang merupakan bentuk pelaksanaan tri dharma perguruan tinggi yang wajib dilakukan istitusi untuk memberikan bekal pengalaman di tempat kerja ke mahasiswa. Jurusan Manajemen Informatika (MI) yang bernaung di bawah Fakultas Teknik dan Kejuruan (FTK) memiliki mata kuliah wajib praktik kerja lapangan (PKL) atau magang yang berbobot 3 SKS. Ternyata magang banyak memberikan dampak yang signifikan terhadap kesuskesan lulusan di dunia kerja. Banyak alumni yang sudah diterima bekerja ditempat magangnya. Dengan berbekal keterampilan di lokasi magang, mahasiswa dapat meningkatkan kompetensinya sesuai dengan permintaan pasar (demand driven). Tentu stakeholders pun memiliki peran penting untuk mengarahkan keterampilan mahasiswa secara langsung sesuai dengan tuntutan dunia industri. Setelah lulus mereka dapat segera direkrut untuk bekerja, bahkan sering ditawarkan untuk menjadi karyawan di tempat magang sebelum mereka lulus.

Menteri Ketenagakerjaan M.Hanif Dhakiri mengatakan dalam acara Dies Natalis ke 36 Universitas Islam Malang bahwa perguruan tinggi memiliki peran strategis untuk meningkatkan sumber daya manusia yang berdaya saing tinggi, karena berdasarkan data dari Badan Pusat Statistik pada Agustus 2016 angka pengangguran mencapai 7,03 juta dari 14,57 juta lulusan tenaga kerja berpendidikan (Nusakini, 2016). Tingginya jumlah pengangguran dapat disebabkan karena masalah lapangan kerja dan kompetensi para pencari kerja yang tidak relevan dengan yang diminta dunia industri. Dalam menangani kesenjangan keterampilan ini maka untuk sekolah vokasi di tingkat sekolah mengengah dan perguruan tinggi mengadakan program agang. Program saat akhir semester 5 di akhir semester mahasiswa sudah harus mencari lokasi magang. Saat itu mahasiswa sering bingung harus melamar lokasi magang, dan terkesan memilih lokasi magang secara sekedar tanpa memikirkan ekspektasi karir ke depannya. Seharusnya mahasiswa dapat memilih tempat magang sesuai dengan kompetensinya masing-masing karena magang adalah salah satu faktor yang berkontribusi penting terhadap kesiapan kerja setelah lulus kuliah. Apabila lulusan sudah memiliki keterampilan yang bagus, ditambah dengan motivasi kerja yang bagus akan sangat memudahkan lulusan untuk diterima bekerja di dunia industri sehingga dapat memperkecil angka pengangguran di Indonesia. (Sirsa et al. 2014) mengatakan bahwa ekspektasi karier, motivasi kerja, dan pengalaman magang sangat berkontribusi terhadap kesiapan kerja. Hal ini menunjukkan berapa signifikannya seorang mahasiswa dalam memilih lokasi magang karena akan berbengaruh besar terhadap keterampilan yang diperoleh dan masa depan mereka di dunia industri.

Adapun tujuan dari penelitian ini adalah memberikan informasi lokasi magang kepada mahasiswa sesuai dengan kompetensi masing-masing. Hal yang paling penting adalah mengarahkan mahasiswa ke lokasi magang yang sesuai dengan kompetensinya karena akan sangat besar pengaruhnya dengan karir mereka di masa depan. Seseorang dikatakan kompeten di suatu bidang apabila memenuhi telah memenuhi aspek pengetahuan, keterampilan, dan sikap. Pengetahuan, keterampilan, dan sikap (PKS) sangat dipengaruhi oleh sistem pembelajaran dan lingkungan belajar. Tools yang dikembangkan adalah sebuah aplikasi yang menggunakan metode Elman Recurrent Neural Network (ERNN). ERNN adalah sebuah metode jaringan syarat tiruan (JST) yang memiliki koneksi umpan balik (feedback) dari masukan sebelumnya, sehingga diharapkan dapat meningkatkan kinerja JST. Struktur tersebut membuat iterasi akan jauh lebih cepat dan konvergensi akan menjadi lebih cepat (Permana and Prijodiprodjo 2014). Sistem yang dikembangkan akan dapat menghasilkan rekomendasi lokasi magang sesuai dengan kompetensi mahasiswa menggunakan data magang sebelumnya.

Adapun tujuan dari penelitian ini adalah membuat rancang bangun dan mengimplementasikan Sistem Rekomendasi Lokasi Magang Berdasarkan Kompetensi Berbasis Artificial Intelligence menggunakan metode Elman Recurrent Neural Network untuk menghasilkan lulusan yang demand driven di Jurusan Manajemen Informatika, Fakultas Teknik dan Kejuruan, Universitas Pendidikan Ganesha.

Demi mewujudkan program pemerintah di bidang pendidikan melalui Nawacita Presiden Republik Indonesia 
Bapak Joko Widodo yang mengatakan bahwa sistem pendidikan vokasi dan pelatihan harus dirombak ke arah deman driven (Humas, 2016). Kompetensi dari lulusan vokasi harus berorientasi ke arah karir di dunia industri. Selama ini kurikulum di perguruan tinggi atau sekolah menengah masih terdapat kesenjangan dengan apa yang diinginkan dunia industri (Suarta, 2010) terutama para stakeholders. Sehingga sebaiknya dalam penyusunan kurikulum seharusnya melihatkan pihak stakeholders. Dalam menguatkan relevansi pendidikan di bangku kuliah dengan lingkungan kerja di dunia industri maka mahasiswa harus mendapatkan lokasi magang yang bagus untuk meningkatkan keterampilannya. Lokasi magang yang baik harus sesuai dengan minat dan kompetensi mahasiswa, sehingga mahasiswa meningkatkan keterampilannya setelah magang. Program magang penting dilaksanakan karena (Sirsa et al. 2014) mengatakan bahwa dengan ekspetasi karier, motivasi kerja, dan pengalaman magang akan sangat berpengaruh terhadap kesiapan kerja. Dengan kompetensi mahasiswa yang baik, diarahkan ke lokasi magang yang sesuai dan pengalaman yang diperolah di lokasi magang akan membuat lulusan percaya diri melamar pekerjaan. Dengan memilih lokasi magang yang tepat, akan membuka peluang karir yang lebih baik untuk mahasiswa. Sehingga lulusan dapat memenuhi kebutuhan dunia industri (deman driven).

\section{TINJAUAN PUSTAKA State Of The Art}

Program magang sangat penting untuk memberikan keterampilan generik dan keterampilan teknis mahasiswa. Dengan mengikuti magang mahasiswa mendapat pengalaman tentang keterampilan yang relevan dengan dunia kerja. Terdapat beberapa penelitian yang terkait dengan topik yang sedang diteliti. Penelitian yang dilakukan Suarta (2010) menyatakan bahwa magang penting dilakukan untuk relevansi nilai-nilai hasil pendidikan untuk memperkecil kesenjangan keterampilan yang dimiliki lulusan dengan dunia kerja sehingga meningkatkan daya serap lulusan. Selain itu dikatakan juga bahwa sistem pembelajaran dan lingkungan belajar harus mendukung pengembangan konsep diri. Konsep diri merupakan prediktor yang signifikan sebagai tahap awal keberhasilan karir lulusan.

PKL dipandang perlu dinilai stakeholders sebagai solusi untuk menjawab tantangan dunia pendidikan yang disebut dengan istilah education mismatch, sehingga menghasilkan pribadi yang bernilai, memiliki sikap dan keterampilan diperlukan sebagai tenaga profesional yang siap bersaing (Julaiha and Kadir 2013). Hal selaras juga disampaikan Wibowo (2015) bahwa dalam mengatasi kesenjangan kompetensi antara dunia pendidikan dengan industri dimana dunia pendidikan menginginkan lulusan mempunyai nilai tinggi dalam waktu cepat, sedangkan dunia industri menginginkan lulusan dengan kompetensi teknis dan

sikap yang baik. Solusi yang dapat diterapkan adalah dengan meningkatkan hard skills dan soft skills (kerjasama dan motivasi), untuk menghasilkan lulusan vokasi yang kompeten. Pembelajaran dapat dilakukan dengan dua prinsip yaitu pembelajaran berbasis kompetensi dan produksi.

Dalam membuat tenaga kerja berpengetahuan dan berketerampilan tergantung pada kualitas pendidikan dan pelatihan. Pendidikan vokasi hendaknya dirancang, dilaksanakan, dan dievaluasi secara terkait (link) sehingga hasilnya sesuai (match) dengan tuntutan dunia industri (Mahfud 2016). Salah satu model pembelajaran vokasi dengan upaya melibatkan pihak dunia usaha atau dunia industri yaitu pembelajaran dengan pendekatan Work-Based Learning (WBL). Kualitas WBL akan dipengaruhi tiga pihak, personal, akademik, dan lokasi magang. Hal ini juga sebagai acuan untuk mengevaluasi kurikulum supaya terjadi relevansi mata kuliah dengan kebutuhan dunia usaha.

Menurut (Kusnaeni and Martono 2016) bahwa karir dipengaruhi motivasi kerja, pengalaman kerja, dan informasi dunia kerja secara signifikan. Apabila ketiga hal ini meningkat, maka akan dapat meningkatkan kesiapan kerja. Meningkatnya kesiapan kerja siswa akan terjadi pada saat siswa mempersiapkan diri dengan berbagai hal tentang pemahaman PKL, membangun sikap kerja, kecakapan dan kebiasaan kerja, menciptakan hubungan kerjasama, mengembangkan tanggung jawab dan menghargai pekerjaan serta para pekerja.. 


\section{Artificial Intelligence}

Artificial Intelligence oleh beberapa kalangan diterjemahkan sebagai kecerdasan buatan, kecerdasan artifisial, intelijensi artificial, atau intelijensi buatan (Suyanto, 2011). Istilah ini sudah akrab bagi orang Indonesia, yang banyak dibicarakan di berbagai media ilmiah maupun non ilmiah. Secara definisi, AI dikelompokkan dalam empat kategori, yaitu :

- Thinking Humanly (Pendekatan Kognitif)

Pendekatan ini melalui dua cara, yaitu introspeksi dengan mencoba menangkap pemikiran-pemikiran kita sendiri pada saat kita berpikir dan yang kedua adalah melalui eksperimen-eksperimen psikologi.

- Acting Humanly (Pendekatan dengan Test Turing)

Pada tahun 1950, Alan Turing melakukan suatu percobaan untuk menguji apakah komputer mampu mengelabui manusia yang menginterogasikan melalui teletype (komukasi jarak jauh berbasis teks). Apabila interrogator tidak dapat membedakan yang diinterogasi adalah manusia atau komputer, maka komputer berintelinjensia tersebut lolos dari tes Turing.

- Thinking Rationally (Pendekatan Bepikir Rasional) Pendekatan ini memiliki dua masalah, yaitu :

a) Tidak mudah untuk membuat pengetahuan informal dan menyatakan pengetahuan tersebut ke dalam aturan formal yang diperlukan oleh notasi logika, khususnya ketika pengetahuan tesebut memiliki tingkat kepastian kurang dari $100 \%$.

b) Terdapat perbedaan besar antara dapat memecahkan masalah "dalam prinsip" dan memecahkan masalah "dalam dunia nyata".

- Acting Rationally (Pendekatan Agent)

Pendekatan ini adalah dengan membuat inferensi logis yang merupakan suatu bagian dari rational agent. Satu-satunya cara untuk melakukan aksi secara rasional adalah dengan menalar secara logis. Dengan menalar secara logis, maka dapat disimpulkan bahwa aksi yang diberikan akan mencapai tujuan atau tidak. Apabila dapat mencapai tujuan, maka agent dapat melakukan aksi berdasarkan kesimpulan tersebut.

Jaringan Syaraf Tiruan (Neural Network)

Jaringan Syaraf Tiruan (JST) didefiniskan sebagai sistem informasi pengolahan yang memiliki karakteristik kinerja tertentu yang sama dengan jaringan syaraf biologis (Fausett, 1994). Berdasarkan dari arsitekturnya, JST dapat dibedakan menjadi dua kategori yaitu struktur feed forward dan recurrent (feedback). Semua ini diawali pada tahun 1943, saat Mc.Culloch dan Pitts memperkenalkan model matematika yang merupakan penyederhanaan dari struktur sel saraf yang sebenarnya. JST dibentuk untuk memecahkan suatu masalah tertentu dimana dalam kehidupan nyata, dimanfaatkan untuk : Perkiraan fungsi atau analisis regresi, termasuk prediksi time series dan modeling, Klasifikasi, termasuk pengenalan pola dan pengenalan urutan, serta pengambil keputusan. Pengolahan data, termasuk penyaringan, pengelompokan, dan kompresi. Bidang Robotik. Menurut Nugroho (2007) JST telah diaplikasikan di berbagai bidang, karena memiliki kelebihankelebihan seperti berikut : Dapat memecahkan problema non-linear yang umum dijumpai di aplikasi. Kemampuan memberikan jawaban terhadap pattern yang belum pernah dipelajari (generalization). Dapat secara otomatis mempelajari data numerik yang diajarkan pada jaringan tersebut. Terdapat tiga hal yang menentukan JST, dalam proses analisa antara lain :

- Hubungan antara neuron-neuron yang dirangkai dalam suatu jaringan (arsitektur)

- Metode untuk menentukan bobot penghubung, sehingga dapat memberikan output yang sesuai pada saat pelatihan (algoritma pembelajaran)

- Fungsi aktivasi yang digunakan untuk menentukan keluaran suatu neuron

\section{Elman Recurrent Neural Network (ERNN)}

Elman Neural Network dianggap sebagai jaringan recurrent yang parsial karena pada umumnya koneksinya hanya berupa feed forward (Fausett, 1994). Elman (1990) menjelaskan bahwa simple recurrent network memiliki arsitektur yang mirip dengan jaringan recurrent state space model dengan 
layer hidden bersifat non linear, namun dengan output layer yang dimungkinkan bersifat non linear tanpa unit delay (dalam Haykin, 1999). Struktur recurrent dikembangkan dari struktur multilayer feed forward.

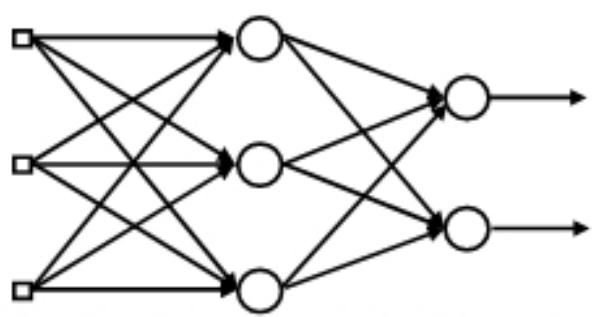

Input layer Hidden layer Output layer

Gambar 1. Multilayer feed forward (Sumber : Siregar, 2011)

\section{Recurrent neural network (RNN)}

Sifat koneksi recurrent ada yang penuh, namun ada juga yang parsial. Koneksi jaringan yang terkoneksi penuh tidak memiliki input layer yang khusus dan setiap neuron memiliki input antara satu dengan yang lainnya. Sedangkan yang terkoneksi secara parsial sangat mirip seperti arsitektur multilayer Gambar 1, namun ditambah dengan feedback dari hidden layer ke bagian context input layer. Arsitektur JST Elman terkoneksi secara parsial, dapat dilihat seperti Gambar 2. Dalam Habarulema (2010), Elman mengatakan bahwa Elman Neural Network adalah modifikasi feed forward dengan perbedaan yang utama adalah pada tambahan layer context neuron yang menyediakan pola hidden unit untuk diumpan balik ke dirinya sendiri. Jaringan recurrent ini memiliki dua buah input, yaitu input sesungguhnya dan contextual input.

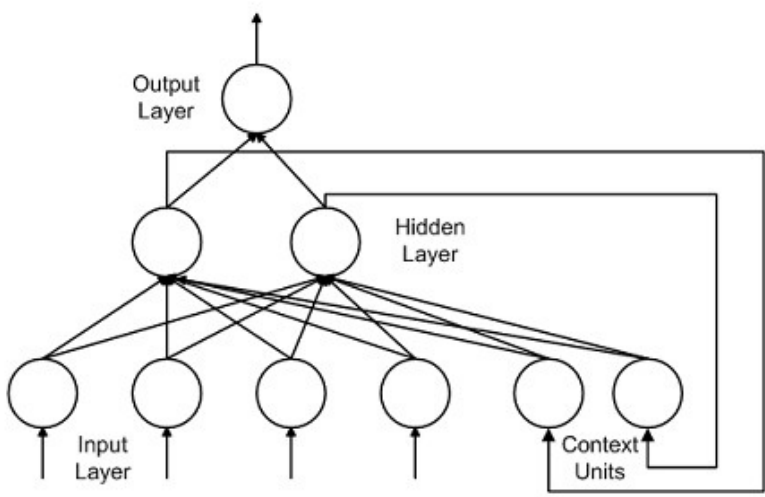

Gambar 2. Elman dengan hidden layer tunggal (Sumber : Hlavacek, 2009)

\section{METODE PENELITIAN Pengumpulan Data}

Proses pengumpulan data dimulai saat mahasiswa D3 Manajemen Informatika mengikuti magang selama 3 bulan dari Januari-Maret Tahun Akademik 2017/2018 yang mengambil lokasi seperti perkantoran, institusi, serta perusahaan.

Pengumpulan data dilakukan dengan observasi langsung ke lapangan serta memberikan form kepada mahasiswa yang akan mengikuti magang dimana lokasi magang yang mereka inginkan serta tes inventory personal untuk mengetahui kompetensi mereka secara afektif.

Selain itu mahasiwa juga mengumpulkan kutipan daftar nilai untuk mengetahui nilai pendukung kompetensi mahasiswa seperti :

- Algoritma pemrograman

- Pemrograman Basis Data

- Multimedia

- Jaringan/Komunikasi Data

Hal ini dilakukan untuk menyesuaikan dengan profil lulusan manajemen informatika yaitu programmer, multimedia, teknisi jaringan, dan administrator database. Kemudian data pendukung lain yang diperlukan adalah indeks prestasi kumulatif sebagai nilai yang mewakili tingkat pengetahuan mahasiswa selama mengikuti perkuliahan. 
Pengumpulan data juga dilakukan melalui kajian pustaka atau studi literatur, yaitu dengan membaca berbagai buku, jurnal, makalah dan bahan bacaan lain sebagai referensi yang dapat dijadikan acuan dalam penelitian. Selain itu data dan informasi yang di butuhkan juga diperoleh dengan mengunjungi berbagai situs-situs terkait yang menyediakan berbagai informasi yang relevan dengan bahasan penelitian

Dalam proses penelitian, metode yang digunakan adalah System Development Live Cycle (SDLC) dengan metode waterfall yang merupakan metode pengembangan perangkat lunak secara sekuensial mengalir dari atas ke bawah (Bassil, 2012). Tahapan metode ini dapat dilihat seperti pada Gambar 3 yang memiliki lima tahapan yaitu pendefinisian masalah, pengumpulan data, analisis sistem, perancangan, pengembangan, pengujian dan evaluasi sistem. Pada proses pendefinisian masalah dilakukan dengan mempertegas kebutuhankebutuhan pengguna terkait dengan sistem yang dikembangkan. Pada tahap ini, harus jelas apa saja yang dibutuhkan pengguna untuk menyelesaikan permasalahan yang sedang dihadapi yaitu tentang memberikan rekomendasi magang yang tepat sesuai dengan kompetensi mahasiswa.

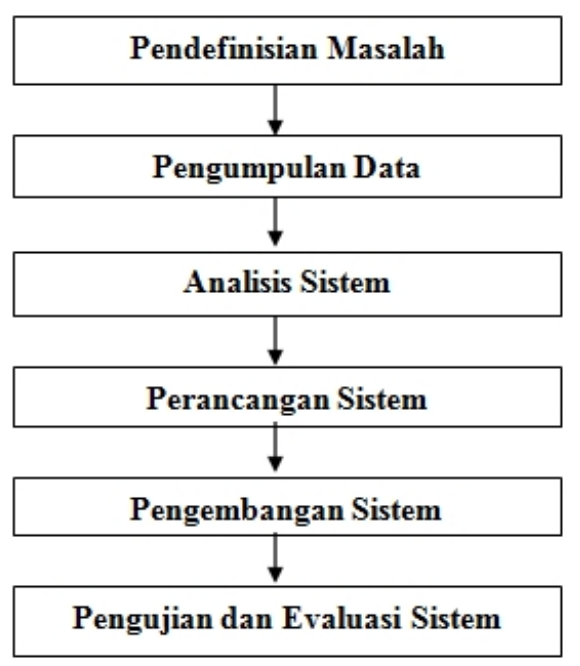

Gambar 3. Tahapan Penelitian

\section{Analisis Sistem}

Dalam tahapan ini diawali dengan melakukan analisis data input, proses yang terjadi, dan hasil yang diharapkan. Dalam mengembangkan sistem ini, data yang digunakan adalah data dari program magang tahun sebelumnya yang sudah di filterisasi. Dalam proses input, digunakan tiga aspek yang mewakili pengetahuan, keterampilan, dan sikap. Ketiga aspek harus memiliki nilai yang terukur, adapun aspek pengetahuan (kognitif) dapat dilihat dari Indeks Prestasi Komulatif (IPK), aspek keterampilan (psikomotorik) dapat dilihat dari nilai mata kuliah yang berhubungan dengan profil lulusan MI yaitu programmer, multimedia, teknisi jaringan, dan administrator database.

Terdapat beberapa mata kuliah yang berhubungan dengan keempat profil lulusan sesuai dengan kurikulum 2016 yaitu mata kuliah algoritma pemrograman (semester 1), pemrograman basis data (semester 2), pengolahan multimedia (semester 3), jaringan dan komunikasi data (semester 4). Aspek sikap (afektif) dapat dinilai menggunakan tes kepribadian yang sudah berstandar internasional yang dikembangkan oleh John Holland, meliputi unsur realistik, investigatif, artistik, sosial, enterpreneur, dan konvensional (Permana and Prijodiprodjo 2014).Sehingga rancangan dari ERRN untuk menentukan lokasi magang dapat dilihat seperti Gambar 4. 


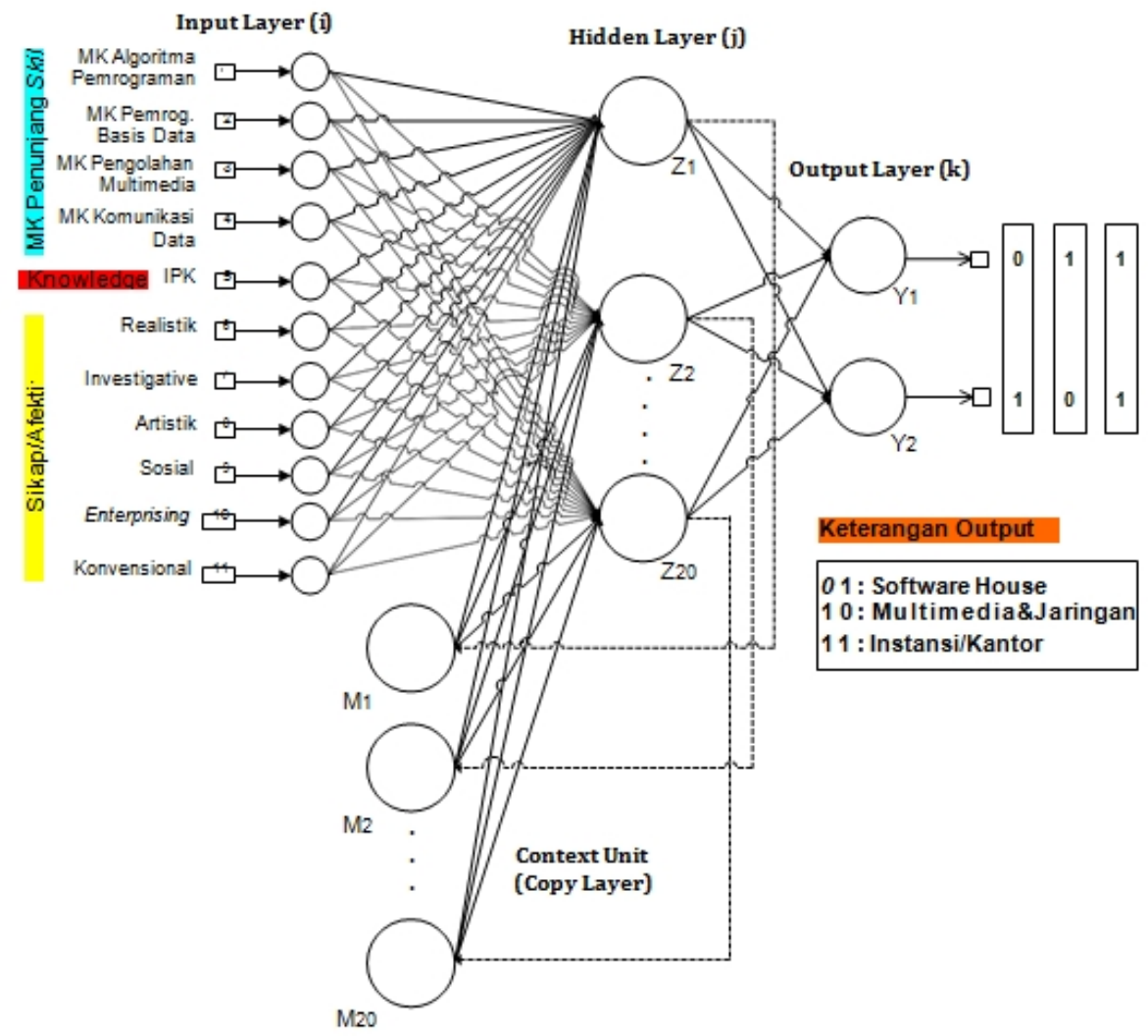

Gambar 4. Rancangan sistem berbasis ERNN

\section{HASIL DAN PEMBAHASAN}

Berdasarkan hasil percobaan dengan melakukan proses training terhadap 17 data mahasiswa magang, data dapat dikenali dengan baik dengan setingan sebagai berikut.

Target error $\quad: \quad 0.0001$

Learning rate : $0.05 / 0.025$ /

0.075

Max epoch : : 5000

Momentum : 0.85

Jumlah hidden : 1

jumlah neuron : $\quad 20$

Percobaan : 2 KaliProses

Pembelajaran Learning Rate(LR) 0.05 dengan settingan seperti Gambar 5, saat melakukan percobaan pertama proses training berhenti saat Epoch : 4504 seperti Gambar 6, dan tingkat akurasi dalam mengenali data seperti berikut (Gambar 7):

$\begin{array}{lll}\text { Akurasi } & & : 47.06 \% \\ \text { Total Data } & & : 17 \\ \text { Dikenali } & & : 8 \\ \text { Tidak dikenali } & : 9 & \end{array}$

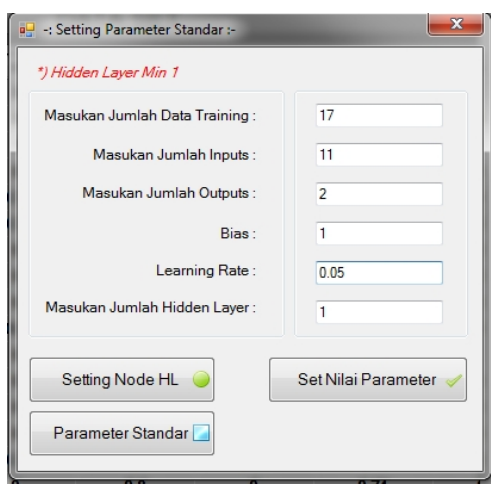

Gambar 5. Setingan Learning Rate 0.05 


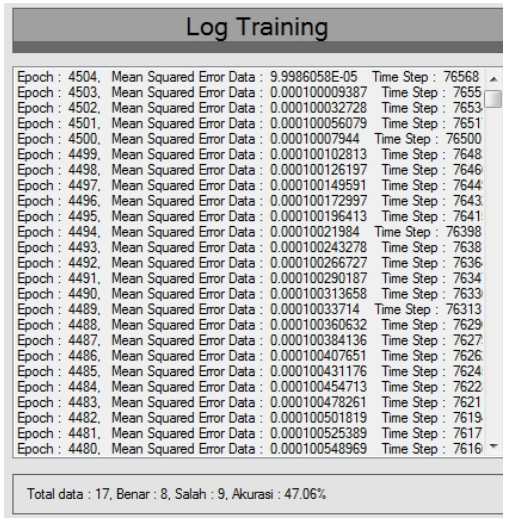

Gambar 6. Epoch Percobaan 1 LR 0.05

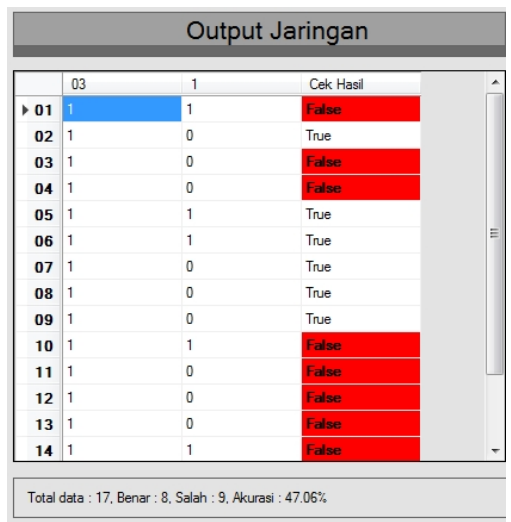

Gambar 7. Akurasi Percobaan 1 LR 0.05 Kemudian saat melakukan percobaan kedua dengan Learning Rate 0.05 , proses training berhenti saat Epoch : 3307 seperti Gambar 8, dan tingkat akurasi dalam mengenali data seperti berikut (Gambar 9):

$\begin{array}{lll}\text { Akurasi } & & : \mathbf{1 0 0 \%} \\ \text { Total Data } & & : 17 \\ \text { Dikenali } & & : 17 \\ \text { Tidak dikenali } & : 0 & \end{array}$

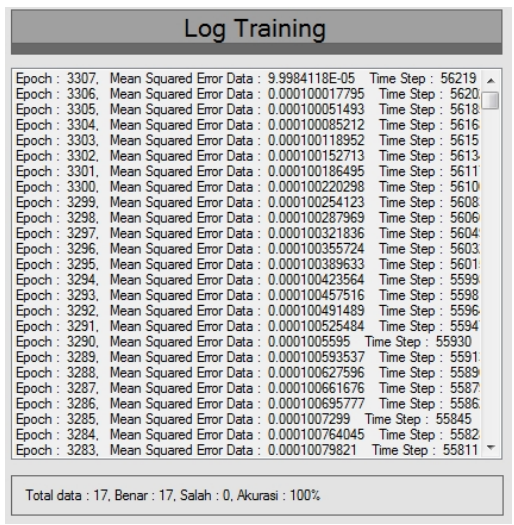

Gambar 8. Epoch Percobaan 2 LR 0.05

\begin{tabular}{|c|c|c|c|c|}
\hline \multicolumn{5}{|c|}{ Output Jaringan } \\
\hline & 03 & 1 & Cek Hasil & . \\
\hline$\not 01$ & 0 & 1 & True & \\
\hline 02 & 1 & 0 & True & \\
\hline 03 & 0 & 1 & True & \\
\hline 04 & 0 & 1 & True & \\
\hline 05 & 1 & 1 & True & \\
\hline 06 & 1 & 1 & True & \\
\hline 07 & 1 & 0 & True & \\
\hline 08 & 1 & 0 & True & \\
\hline 09 & 1 & 0 & True & \\
\hline 10 & 0 & 1 & True & \\
\hline 11 & 0 & 1 & True & \\
\hline 12 & 0 & 1 & True & \\
\hline 13 & 0 & 1 & True & \\
\hline 14 & 0 & 1 & True & . \\
\hline
\end{tabular}

Gambar 9. Akurasi Percobaan 2 LR 0.05

Proses Pembelajaran Learning Rate(LR) 0.025 dengan settingan seperti Gambar 10, saat melakukan percobaan pertama proses training berhenti saat Epoch : 6920 seperti Gambar 11, dan tingkat akurasi dalam mengenali data seperti berikut (Gambar 12):

$\begin{array}{lll}\text { Akurasi } & & : \mathbf{4 7 . 0 6 \%} \\ \text { Total Data } & & : 17 \\ \text { Dikenali } & & : 8 \\ \text { Tidak dikenali } & : 9 & \end{array}$

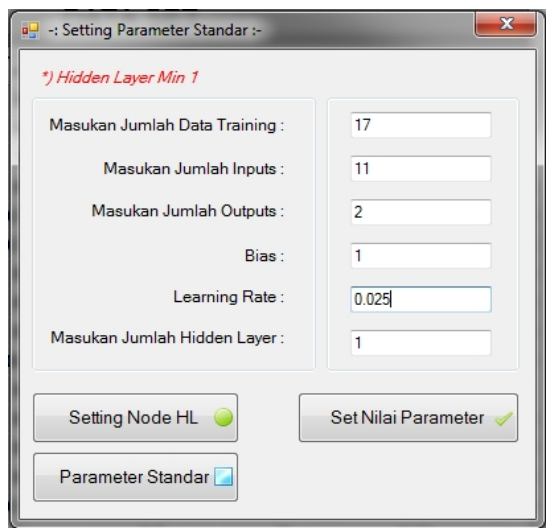

Gambar 10. Setingan Learning Rate 0.025 


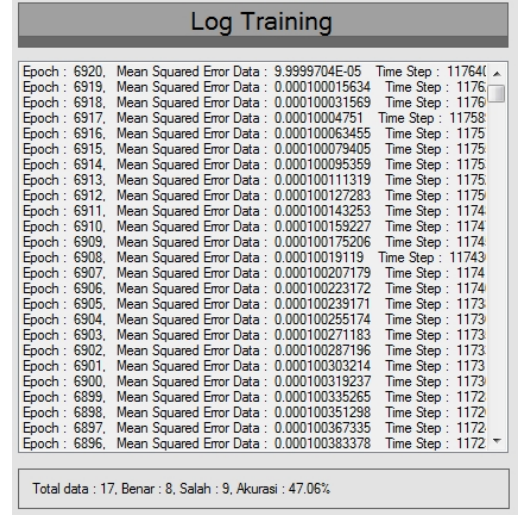

Gambar 11. Epoch Percobaan 1 LR 0.025

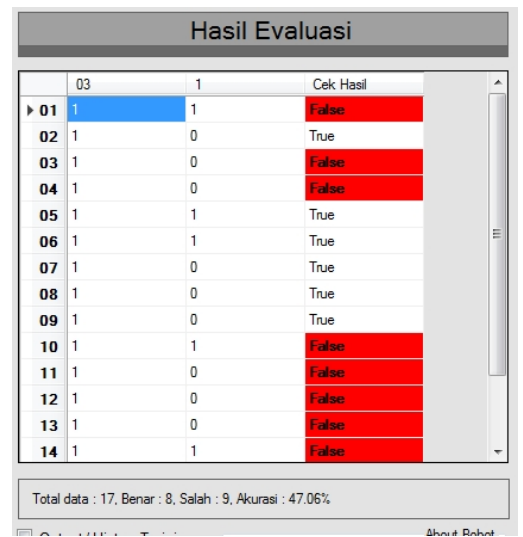

Gambar 12. Akurasi Percobaan 1 LR 0.025

Kemudian saat melakukan percobaan kedua dengan Learning Rate 0.025 , proses training berhenti saat Epoch : 7289 seperti Gambar 13, dan tingkat akurasi dalam mengenali data seperti berikut (Gambar 14):

\begin{tabular}{|c|c|}
\hline Akurasi & : $52.94 \%$ \\
\hline Total Data & $: 17$ \\
\hline Dikenali & $: 9$ \\
\hline
\end{tabular}

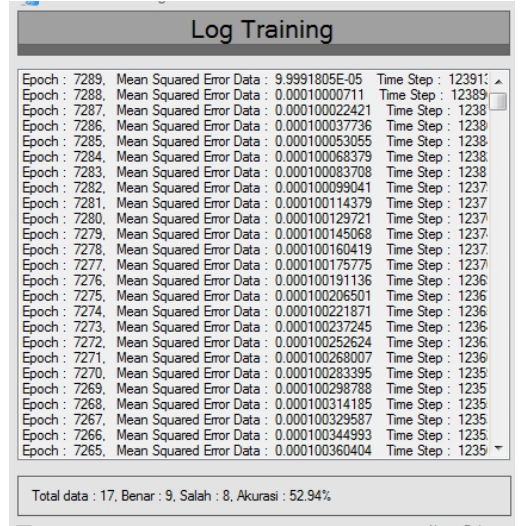

Gambar 13. Epoch Percobaan 1 LR 0.025

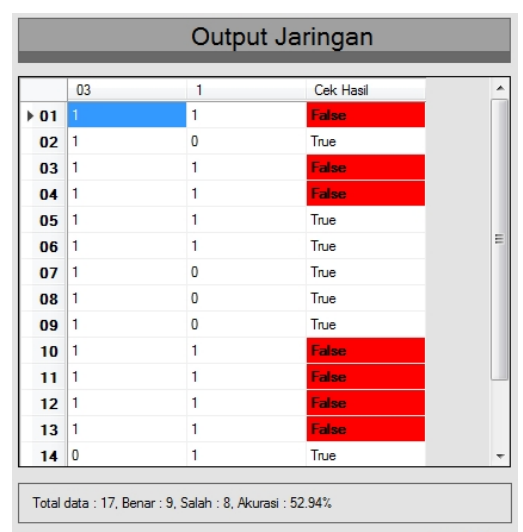

Gambar 14. Akurasi Percobaan 1 LR 0.025

\section{SIMPULAN}

Pengembangan aplikasi rekomendasi lokasi magang berbasis ERNN berhasil dirancang dan dikembangkan. Melalui proses uji coba, sistem telah mampu mengenali data latih dengan baik dengan akurasi mencapai 100\% dan target error 0.0001. Proses training dilakukan dengan mengubah nilai learning rate $0.25,0.05$, dan 0.75 dimana hasil yang paling bagus adalah saat nilai learning rate 0.05. namu untuk setingan lain seperti jumlah layer dan jumlah node per layer perlu dilakukan uji lebih lanjut lagi. 


\section{DAFTAR PUSTAKA}

[1] Bassil, Youssef. 2012. A Simulation Model for the Waterfall Software Development Life Cycle.International Journal of Engineering \& Technology (iJET), Vol. 2, No 5

[2] Boden, M., 2001, A guide to recurrent neural network dan backpropagation, Computer and Electrical Engineering, Halmstad University, 13 November 2001

[3] Fauset, L. 1994, Fundamentals of Neural Network: Architectures, Algorithms, and Application, Pretice-Hall : New Jersey

[4] Haykin, S., 1999, Neural Network A Comprehensive Foundation, Second Edition, Pearson Education, Singapore

[5] Humas, 2016. Mayoritas Pengangguran Lulusan SMK, Presiden Jokowi Minta Sistem Pendidikan Vokasi Dirombak. http://setkab.go.id/category/berita/ (diakses : 16 Juni 2017, 12:24)

[6] Hlavacek, M., 2009, Seasonal Time Series Modeling Via Neural Networks With Switching Units, Thesis, Faculty Of Nuclear Sciences And Physical Engineering, Czech Technical University, Prague

[7] Julaiha, S., and M. Kadir. 2013. "Samarinda, Analisis Penilaian Stakeholders Terhadap Pelaksanaan Praktik Kerja Lapangan (PKL) Mahasiswa Program Studi (Prodi) Manajemen Pendidikan Islam (Mpi) Stain." FENOMENA V (1): 133-46.

[8] Kusnaeni, Yuyun, and S Martono. 2016. "Pengaruh Persepsi Tentang Praktik Kerja Lapangan, Informasi Dunia Kerja Dan Motivasi Memasuki Dunia Kerja Terhadap Kesiapan Kerja Siswa SMK" 5 (1): 16-29.

[9] Mahfud, Tuatul. 2016. "Evaluasi Program Praktik Kerja Lapangan Jurusan Tata Boga Politeknik Negeri Balikpapan.” Jurnal Pendidikan Teknologi Dan Kejuruan 23: 110- 16.

[10] Nugroho, A. S., 2007, Menggairahkan Riset SoftComputing di Indonesia, Seminar
Nasional Riset Teknologi Informasi STMIK AKAKOM, Yogyakarta, 7 Juli 2007

[11] Noorviani, Y., 2011, Penerapan Elman Recurrent Neural Network untuk Diagnosis Ganguan Autis Pada Anak, Tesis, Fakultas Matematika dan Ilmu Pengetahuan Alam, Program Studi S2 Ilmu Komputer, Universitas Gadjah Mada, Yogyakarta (tidak dipublikasikan)

[12] Permana, Agus Aan Jiwa, and Widodo Prijodiprodjo. 2014. "Sistem Evaluasi Kelayakan Mahasiswa MagangMenggunakan Elman Recurrent Neural Network." IJCCS (Indonesian Journal of Computing and Cybernetics Systems) 8 (1): 37 48. doi:10.22146/ijccs.3494.

[13] Sirsa, I Made, Nyoman Dantes, I Gusti Ketut, and Arya Sunu. 2014. "Kontribusi Ekspektasi Karier, Motivasi Kerja, Dan Pengalaman Kerja Industri Terhadap Kesiapan Kerja Siswa Kelas Xii Smk Negeri 2 Seririt.” E-Journal Program Pascasarjana Universitas Pendidikan Ganesha Program Studi Administrasi Pendidikan 5.

[14] Siregar, B. O., 2011, Prediksi Kebutuhan Daya Listrik Menggunakan Jaringan Saraf Tiruan dengan Menggunakan Metode Reccurent, Proposal Penelitian, Fakultas Teknik Elektro, Universitas Sriwijaya, Palembang

[15] Suarta, I Made. 2010. "Hubungan Sistem Pembelajaran, Lingkungan Belajar, Konsep Diri Dan Pengembangan.” Jurnal Penelitian Dan Evaluasi Pendidikan, 24-41.

[16] Suhartanta, Z. Arifin, 2012. Jejaring Kerja Sama Sebagai Upaya Meningkatkan Kualitas dan Daya Saing Lulusan Pendidikan Kejuruan, Seminar Internasional (APTEKINDO), ISSN 1907-2066

[17]Suyanto, 2011. Artificial Intelligence (Searching, Reasoning, Planning dan Learning).

[18] Bandung: Informatika 
Permana, Pradnyana, Sistem Rekomendasi Lokasi Magang Berdasarkan Kompetensi Berbasis. 108

[19] Wibowo, Nugroho. 2015. "Upaya

Memperkecil Kesenjangan

Kompetensi Lulusan Sekolah

Menengah Kejuruan Dengan

Tuntutan Dunia Industri.” Jurnal

Pendidikan Teknologi Dan

Kejuruan 23: 45-50. 